Controversies in

\section{Therapeutics}

\title{
Role of diet in treating atopic eczema: elimination diets can be beneficial
}

\author{
David J Atherton
}

Children with atopic eczema have a high frequency of immediate positive skin test reactions to foods and high circulating titres of $\mathrm{IgE}$ specific to food, as measured by the radioallergosorbent test. They commonly experience food induced hypersensitivity reactions of rapid onset, both cutaneous - for example, contact urticaria and acute generalised urticaria-and noncutaneous - for example, vomiting. The underlying mechanism for such reactions is probably classical type I hypersensitivity. Double blind, placebo controlled food challenges have been used to show the frequency of these rapid onset reactions to foods, 'their association with a concurrent rise in plasma histamine concentration, ${ }^{2}$ and their close correlation with positive results in skin prick tests and circulating IgE antibody values. ${ }^{3}$

Contact urticaria is the rapid development of erythema or weals, or both, at the site of direct cutaneous antigen contact. When parents describe the appearance or worsening of skin lesions immediately after their child with eczema has eaten they are usually describing contact urticaria to food antigens. Failing to be aware of contact urticaria is probably the main reason for medical scepticism of parental descriptions of skin reactions induced by foods in their children who have eczema.

Children who experience contact urticaria or other reactions of rapid onset induced by foods should clearly avoid exposure to the causative agents. The occurrence of such reactions does not, however, establish a role for foods in the cause of atopic eczema itself.

\section{Elimination diets}

Several authors have reported the successful dietary treatment of atopic eczema. Most of these reports have described open studies of empirically selected elimination diets (reviewed by Pike and Atherton ${ }^{4}$ ). Unfortunately, the results obtained in such studies are likely to be highly subjective, and to show that elimination diets are truly beneficial requires placebo

Hospital for Sick Children, London WC1N 3JH David J Atherton, FRCP, consultant in paediatric dermatology

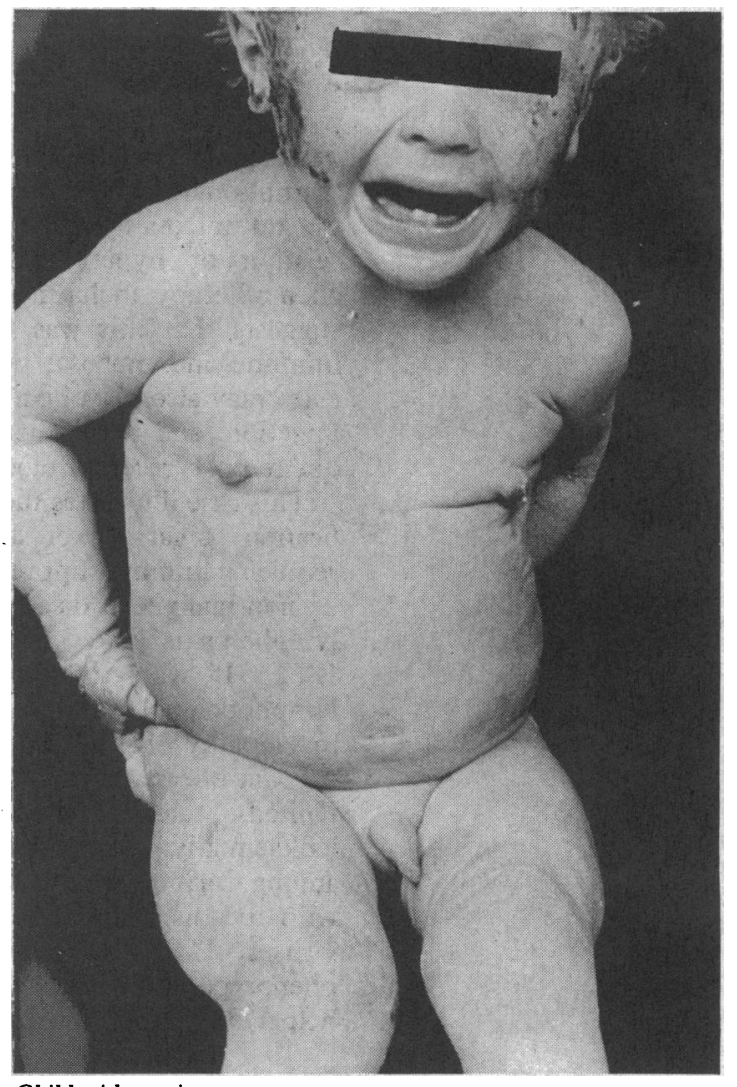

Child with atopic eczema

controlled studies. Sadly, data are only available from two such studies.

The first was that of our own group. ${ }^{5}$ The trial diet entailed completely avoiding egg and milk, with soya formula substituting for milk. The control diet similarly avoided egg and milk but the children were given a combination of dried egg and cows' milk in place of the soya formula. A double blind, cross over design was used. Over half the children showed a clear preference for the diet genuinely excluding egg and milk. Of interest was the finding that many children benefited from avoiding egg and milk without any previous parental suspicion that these foods could aggravate their children's eczema. We also found no association between the response to the diet and the presence of positive immediate skin test results and raised titres of $\mathrm{IgE}$ antibodies to egg or milk antigens.

The second controlled study had a similar experimental design, but included both adults and children. ${ }^{6}$ This showed a smaller overall rate of response of $25 \%$ (35\% in those under the age of 8 years). This somewhat less striking response may reflect the recent increased exposure of babies to soya, thus making soya a less satisfactory substitute for milk. A more important reason for the smaller proportion of responders in this study may, however, be related to the fact that today few children attend a dermatology clinic whose parents have not already attempted unsupervised dietary treatment. Children responding to such manipulations are less likely to be referred, so those now seen in hospital will to some extent be selected for their unlikeliness to benefit from a simple elimination diet.

Other studies have addressed the possible procontinued on page 1460
Contact urticaria to egg occurring in 3 year old boy with atopic eczema. Pictures were taken before (left) and 15 minutes after (right) application of raw egg white to cheek. Reprinted with permission of $\mathcal{F}$ Brostoff, Sf Challacombe, eds. Food Allergy and Intolerance. London: Baillière Tindall, 1987:585 


\section{Controversies in \\ Therapeutics}

David J Atherton

continued from page 1458 vocative role of a wider variety of foods. Hathaway and Warner reported their experience in a group of $\mathbf{4 0}$ eczematous children who were responsive to diet. ${ }^{7}$ Those not helped by simple empirical diets had been given increasingly restrictive diets until improvement occurred. Seven of the 40 children responded to excluding egg and milk alone, 30 responded to more restricted diets, and three improved only when given an elemental feed. An attempt was then made to identify the provocative foods, checked by double blind challenges. In addition to milk and eggs, commonly implicated foods included citrus fruits, colourings and preservatives, nuts, fish, wheat, tomatoes, lamb, chicken and soya, showing that unresponsiveness to a simple diet does not necessarily exclude a provocative role for foods in individual patients.

\section{Conclusions}

The evidence from published studies and our own experience, suggests that a proportion of children with atopic eczema will benefit from dietary elimination of selected foods. Several foods may need to be excluded, and currently available tests will not reliably identify them. The proportion of children likely to benefit is probably not less than a quarter and not greater than a half. Whether this rate of response could be improved by developing more accurate methods for identifying provocative foods is an important but unanswered question. How long the benefit of dietary modification may be maintained is also unclear. Our practice is to consider a trial of a simple, empirical exclusion diet in any children below the age of 8 years in whom adequate topical treatment has been insufficiently beneficial. ${ }^{8}$ Children with atopic eczema should not be treated with diets as a matter of routine. Elimination diets should not be continued long term without good evidence of benefit, and their nutritional sufficiency should be carefully checked.

1 Sampson HA. Role of immediate food hypersensitivity in the pathogenesis of atopic eczema. F Allergy Clin Immunol 1983;71:473-80.

2 Sampson HA, Jolie PL. Increased plasma histamine concentrations after food challenges in children with atopic eczema. $N$ Engl $\mathcal{H}$ Med 1984;311:372-6.

3 Sampson HA, Albergo R. Comparison of results of skin tests, RAST, and double-blind, placebo-controlled food challenges in children with atopic dermatitis. F Allergy Clin Immunol 1984;74:26-33.

4 Pike M, Atherton DJ. Atopic eczema. In: Brostoff J, Challacombe SJ, eds. Food allergy and intolerance. London: Baillière Tindall, 1987:583-601.

5 Atherton DJ, Sewell M, Soothill JF, Wells RS, Chilvers CED. A double-blind controlled crossover trial of an antigen-avoidance diet in atopic eczema. Lancet 1978; i:401-3.

6 Neild VS, Marsden RA, Bailes JA, Bland JM. Egg and milk free exclusion diets in atopic eczema. Br f Dermatol 1986;114:117-23.

7 Hathaway MJ, Warner JO. Compliance problems in the dietary management of eczema. Arch Dis Child 1983;58:463-4.

8 Atherton DJ. Diet and atopic eczema. Clin Allergy 1988;18:215-28.
Roger Allen

continued from page 1459 may persuade the parents to exclude unnecessarily from the diet any prepared foods containing such ingredients.

Food additives have also been blamed for exacerbating eczema, but as Lessof et al pointed out there is no logic in considering additives as a unified group, such is the wide range of chemicals included under this heading. ${ }^{15}$ The dye tartrazine has been incriminated most frequently in view of its effect in urticaria, but, although it releases histamine, a survey of the prevalance of reactions to food additives in 18582 people failed to identify one in whom the challenge produced eczema. ${ }^{16}$

\section{Conclusion}

Dietary factors are not the cause of atopic eczema, and I think that any substantial evidence that they cause it to worsen is lacking. There is a risk that exclusion diets inexpertly used in children will in providing inadequate nutrition do harm, ${ }^{17}$ and I therefore see no grounds on which to recommend manipulating the diet as a form of treatment and strongly discourage my patients from doing so.

1 Lynch NR, Medouze L, Di Preso-Fuenmayor MC, Verde O, Lopez RI, Malave C. Incidence of atopic disease in a tropical environment: partial independence from intestinal helminthiasis. $\mathcal{F}$ Allergy Clin Immunol 1984 73:229-33.

Anonymous. Breast feeding and atopic eczema [Editorial]. Br Med f 1983;287 775-6.

3 Atherton DJ. The role of foods in atopic eczema. Clin Exp Dermatol 1983;8:227-32.

Grulee CG, Sanford HN. The influence of breast and artificial feeding on infantile eczema. I Pediatr 1936;9:223-5.

5 Bonfazi E, Garofalo L, Monterisi A, Menghini CL. History of food allergy, RAST and challenge tests in atopic dermatitis. Acta Derm Venereol (Stockh) 1980;92:91-3.

6 van Asperen PP, Kemp AS, Mellis CM. Relationship of diet in the development of atopy in infants. Clin Allergy 1984;14:525-32.

7 Hansen AE. Essential fatty acid deficiency in atopic eczema. Proc Soc Exp Biol Med 1933;31:160-1.

8 Manku MS, Horrobin DF, Morse N, Wright S, Burton JL. Essential fatty acids in the plasma phospholipids of patients with atopic eczema. $B r f$ Dermatol 1984;110:643-8.

9 Gibson RA, Kneebone GM. Fatty acid composition of human colostrum and mature breast milk. Am f Clin Nutr 1981;34:252-7.

10 Hudson BJF. Evening primrose (Oenothera spp) oil and seed. fourmal of the American Oil Chemists Society 1984;61:540-3.

11 Wright S, Burton JL. Oral evening primrose oil improves atopic eczema. Lancet 1982; ; 1120-2.

12 Bamford JTM, Gibson RW, Renier CM. Atopic eczema unresponsive to evening primrose oil. F Am Acad Dermatol 1985;13:959-65.

13 Pearson DJ. Food allergy, hypersensitivity and intolerance. $f R$ Coll Physicians Lond 1985;19:154-62.

14 Halpern SR, Sellars WA, Johnson RB, Anderson DW, Saperstein S, Reisch JS. Development of childhood allergy in infants fed breast, soy or cow's milk. F Allergy Clin Immunol 1973;51:139.

15 Lessof MH, Wraith DG, Merrett J, Buisseret PD. Food allergy and intolerance in 100 patients-local and systemic effects. Qf Med 1980;195: intolerance. $259-71$.

16 Lessof MH. Adverse reactions to food additives. $\mathcal{F} R$ Coll Physicians Lond 1987;21:237-40.

17 Caputo RV, Frieden I, Krafchik BR, et al. Diet and atopic dermatitis. $\mathcal{f}$ Am Acad Dermatol 1986;15:543-5.

\section{ANY QUESTIONS}

Sodium is said to increase the urinary excretion of calcium, and osteoporosis has been attributed partly to the salt content of the Western diet. If so can sodium bicarbonate be justified as an ingredient of a calcium supplement?

There is good evidence both in man and in rats that increased sodium chloride intake increases urinary calcium excretion and is associated with raised serum concentrations of parathyroid hormone. The initial effect is mediated at a renal level, where tubular reabsorption of calcium is closely linked to that of sodium. Susceptibility to osteoporosis is determined by age, sex, race, and a host of local bone and systemic factors, which include urinary calcium excretion and calcium intake. ' While salt loading leads to osteopenia in animals, ${ }^{2}$ there is as yet no direct evidence in man linking sodium intake to accelerated bone loss. It is illogical, however, to prescribe calcium in a preparation that is likely to affect adversely calcium balance. Furthermore, sodium intake in Western communities is excessive. It probably contributes to an increased blood pressure with age ${ }^{3}$ and is likely in salt sensitive individuals to raise blood pressure in the short term. It seems unwise, therefore, to prescribe sodium bicarbonate as an ingredient of a calcium supplement when alternative preparations are available. - I PERRY, research registrar, D G BEEVERS, consultant physician, Birmingham

1 Laurence GR. Local and systemic factors in the pathogenesis of osteoporosis. N Engl I Med 1988;318:818-28.

2 Goulding A, Everitt HE, Cooney JM, Spears GFS. Sodium and osteoporosis. In: Wahlqist ML, Truswell AS, eds. Recent advances in clinical nutrition. London: John Libbey, 1986:99-108.

3 Intersalt Cooperative Research Group. Intersalt: an international study of electrolyte excretion and blood pressure. Results for 24 hour urinary sodium and potassium excretion. $\mathrm{Br} \mathrm{Med} \mathcal{J}$ and blood pressure. 